\title{
Site effect classification based on microtremor data analysis using a concentration-area fractal model
}

\author{
A. Adib ${ }^{1}$, P. Afzal ${ }^{2}$, and K. Heydarzadeh ${ }^{3}$ \\ ${ }^{1}$ Department of Mining Engineering, Faculty of Engineering, South Tehran Branch, Islamic Azad University, Tehran, Iran \\ ${ }^{2}$ Camborne School of Mines, University of Exeter, Penryn, UK \\ ${ }^{3}$ Zamin Kav Environmental \& Geology Research Center, Tehran, Iran
}

Correspondence to: A. Adib (adib@azad.ac.ir)

Received: 24 April 2014 - Published in Nonlin. Processes Geophys. Discuss.: 22 July 2014

Revised: 4 December 2014 - Accepted: 13 December 2014 - Published: 27 January 2015

\begin{abstract}
The aim of this study is to classify the site effect using concentration-area $(C-A)$ fractal model in Meybod city, central Iran, based on microtremor data analysis. Log$\log$ plots of the frequency, amplification and vulnerability index $(k-g)$ indicate a multifractal nature for the parameters in the area. The results obtained from the $C-A$ fractal modelling reveal that proper soil types are located around the central city. The results derived via the fractal modelling were utilized to improve the Nogoshi and Igarashi $(1970,1971)$ classification results in the Meybod city. The resulting categories are: (1) hard soil and weak rock with frequency of 6.2 to $8 \mathrm{~Hz}$, (2) stiff soil with frequency of about 4.9 to $6.2 \mathrm{~Hz}$, (3) moderately soft soil with the frequency of 2.4 to $4.9 \mathrm{~Hz}$, and (4) soft soil with the frequency lower than $2.4 \mathrm{~Hz}$.
\end{abstract}

\section{Introduction}

Site effect caused by an earthquake may vary significantly in a short distance. The seismic wave trapping phenomenon leads to amplified vibration amplitudes that may increase hazards in sites with soft soil or topographic undulations. Theoretical analysis and observational data have illustrated that each site has a specific resonance frequency at which ground motion gets amplified (Bard, 2000; Mukhopadhyay and Bormann, 2004).

Microtremor data analysis is applied in the recognition of the soil layers, prediction of shear-wave velocity of the ground, and evaluation of the predominant period of the soil during earthquake events. It has been proved that measurement and analysis of microtremor data is an efficient and low-cost method of seismic hazard microzonation (Kanai and Tanaka, 1954; AIJ, 1993; Mukhopadhyay and Bormann, 2004; Beroya et al., 2009). Microtremors are weak ground motions with amplitude between 1 and $10 \mu \mathrm{m}$ which always exist and are mostly generated by natural processes. Since these motions change the site effects and these changes are representative of the soil characteristics, microtremor analysis is used to obtain information about soil vibration properties of sites (Kamalian et al., 2008).

Some scientists believe that microtremors are mostly formed by Love and Rayleigh waves (Akamatu, 1961). However, they can also be composed of Longitudinal and Rayleigh waves (e.g. Douze, 1964). Allam (1969) proposed that microtremors could be composed of body and/or surface waves and thus, it is possible that they are originated from any wave.

Microtremors are also applied to calculate the amplifications of horizontal movements in the free surface during earthquake events (Nakamura, 1989). Fundamentally, the method expresses the spectral amplification of a surface layer obtained by evaluation of the horizontal-to-vertical spectral ratio of recorded microtremors. The amplification factor was a result of several refracted waves in effect of their incidence into layer boundary. Thus, the associated Rayleigh wave of a microtremor would be a noise and would be removed during the $H / V$ process. Moreover, $H / V$ ratios of simultaneously measured records on ground surface and bedrock showed a constant maximum acceleration ratio. Since every station has different characteristics, the records of one earthquake in various sites will be different. In a soft-soil location underlying a hard rock, the $H / V$ spectral ratio displays a clear 


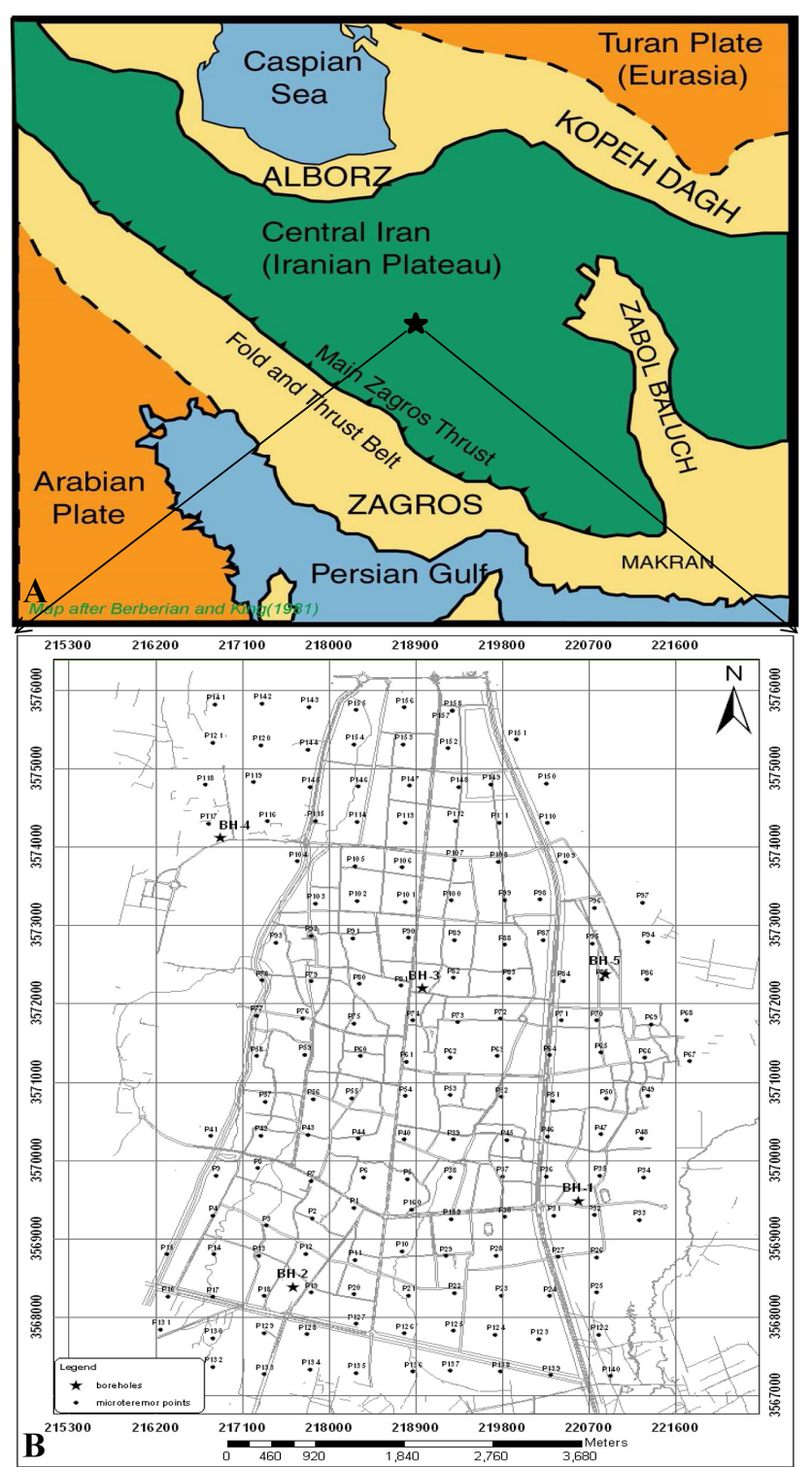

Figure 1. (a) Location of the study area (black star) in Iran; (b) map of the microtremor recording points and boreholes.

peak. These peaks are spatially and temporally stable and can be considered as a fundamental (resonance) frequency of the site (Duval, 1994, 1996). This method is used by many scientists in order to identify small-scale seismic risks and prepare detailed data for urban seismic microzonation. Konno and Ohmachi (1998) carried out a thorough study of Nakamura's approximation and investigated multi-layered systems - known as the HVSR method. Numerical studies of horizontal geological deposits show that if there are large impedance differences between deposits and bedrock, the local fundamental frequency can be well presented by the HVSR method. However, comparison of HVSR peaks with the standard spectral ratio shows that the actual site ampli-

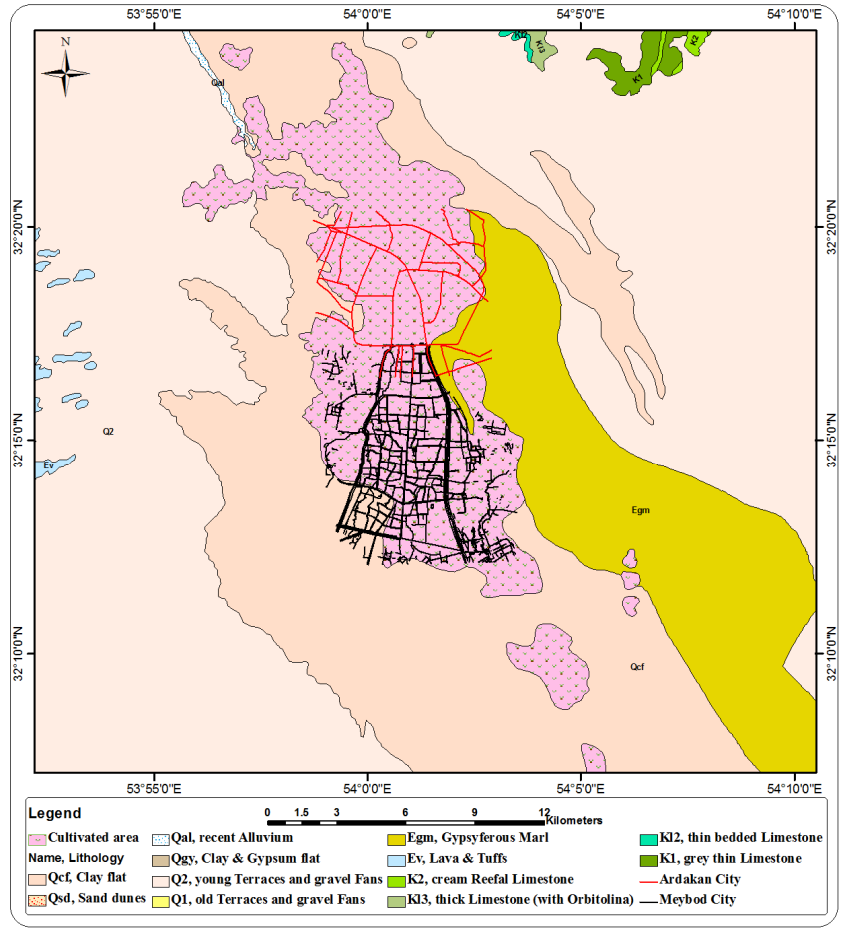

Figure 2. Geological map of Meybod area. According to the map, the major units around the city are Quaternary deposits including cultivated land, Clay flat and young terraces and fans. The only other unit close to the city is Eocene gypsiferous marl (Egm).

fication cannot be estimated from the amplitudes of HVSR peaks (Bard, 1998; Gosar et al., 2008; SESAME, 2004).

Identification of ground types is a main issue in the seismic geotechnical studies as well as site selection. There are many site effect classifications based on dynamical ground characteristics such as frequency, period, alluvial thickness and shear-wave velocity. Nogoshi and Igarashi (1971) proposed one of the common classifications of site effects (Table 2).

Additionally, Komak Panah et al. (2002) presented a classification based on the HVSR method in eastern and central Iran. Both used fundamental frequency as a main factor (Tables 1 and 2).

Euclidean geometry recognizes geometrical shapes with an integer dimension; 1-D, 2-D and 3-D. However, there are many other shapes or spatial objects whose dimensions cannot be mathematically explained by integers, but by real numbers or fractions. These spatial objects are called fractals. In abstract form, fractals describe complexity in data distribution by estimation of their fractal dimensions. Different geophysical and geochemical processes can be described based on differences in fractal dimensions obtained from analysis of relevant geophysical data. Fractal models, established by Mandelbrot (1983), were applied to objects that were too irregular to be described by ordinary Euclidean geometry (Davis, 2002; Evertz and Mandelbrot, 1992). Fractal theory has been of practical use to geophysical and geochem- 
Table 1. Site effect classification of Komak Panah et al. (2002).

\begin{tabular}{lrrll}
\hline $\begin{array}{l}\text { Geological } \\
\text { Condition }\end{array}$ & $\begin{array}{r}V_{\mathrm{s}}^{30} \\
\left(\mathrm{~m} \mathrm{~s}^{-1}\right)\end{array}$ & $\begin{array}{r}\text { Predominant } \\
\text { frequency }(\mathrm{Hz})\end{array}$ & $\begin{array}{l}\text { Soil } \\
\text { description }\end{array}$ & $\begin{array}{l}\text { Class } \\
\text { no. }\end{array}$ \\
\hline $\begin{array}{l}\text { Thick soft clay or silty sandy clay } \\
\text { mostly alluvial plain }\end{array}$ & $<350$ & $<2.5$ & Soft soil & I \\
\hline $\begin{array}{l}\text { Interbedded of fine and coarse } \\
\text { material, alluvium terraces with } \\
\text { weak cementation }\end{array}$ & $350-550$ & $2.5-5$ & $\begin{array}{l}\text { Moderately } \\
\text { soft soil }\end{array}$ & IIa \\
\hline $\begin{array}{l}\text { Thick old alluvium terraces or } \\
\text { colluviums soils with medium to } \\
\text { good cementation }\end{array}$ & $550-750$ & $5-7.5$ & Stiff soil & IIb \\
\hline $\begin{array}{l}\text { Well cemented and compacted soil, } \\
\text { old quaternary outcrop }\end{array}$ & $>750$ & & & \\
\hline
\end{tabular}

Table 2. Site effect classification of Nogoshi and Igarashi (1970).

\begin{tabular}{|c|c|c|}
\hline Description & Frequency (Hz) & Type \\
\hline $\begin{array}{l}\text { Stiff rock composed of gravel, sand and other soils mainly consisting of tertiary } \\
\text { or older layers }\end{array}$ & $7-10$ & I \\
\hline $\begin{array}{l}\text { Sandy gravel, stiff sandy clay, loam or sandy alluvial deposits whose depths are } \\
5 \mathrm{~m} \text { or greater }\end{array}$ & $4.5-7$ & II \\
\hline Standard grounds other than type I, II or IV & $2-4.5$ & III \\
\hline $\begin{array}{l}\text { Soft alluvium-delta lands and pit whose depth is } 20 \mathrm{~m} \text { or greater. Reclaimed land } \\
\text { from swamps or muddy shoal where the ground depth is } 2 \mathrm{~m} \text { or greater and less } \\
\text { than } 20 \text { years have passed since the reclamation. }\end{array}$ & $0.1-2$ & IV \\
\hline
\end{tabular}

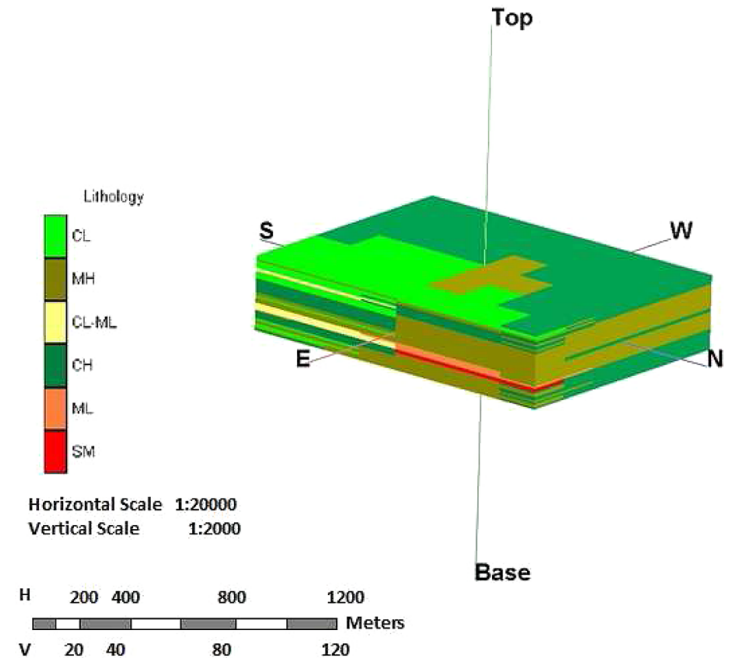

Figure 3. 3-D model of soil deposits of Meybod city, Iran. Dominant soil type is composed of clay and silt with high plasticity. The major variation is located in the eastern part of the city (CL: inorganic clay of low plasticity or lean clay; $\mathrm{MH}$ : inorganic silt of high plasticity; CL-ML: inorganic clay and inorganic silt of low plasticity; $\mathrm{CH}$ : inorganic clay of high plasticity; ML: inorganic silt of low plasticity; SM: silty sand). ical exploration since late 1980s (e.g. Agterberg et al., 1996; Afzal et al., 2010, 2011, 2012, 2013; Cheng et al., 1994; Daneshvar et al., 2012; Sim et al., 1999; Turcotte, 1986). Cheng et al. (1994) proposed a concentration-area $(C-A)$ fractal model based on the relationship of elemental distributions and occupied areas. This idea and premise provided a scientific tool to demonstrate that an empirical relationship of $C-A$ exists in the geophysical and geochemical data (Afzal et al., 2010, 2012; Cheng et al., 1994; Cheng, 1999; Goncalves et al., 2001; Sim et al., 1999). Cheng et al. (1994) showed that there are various parameters which have a key role in spatial distributions of most of the elements for a given geologicalgeochemical environment.

In this paper, fundamental frequency, amplification and ground vulnerability index ( $K-g$ value) data of Meybod city (central Iran) are separated by $C-A$ fractal model and Nogoshi's classification. Subsequently, results obtained by the two methods are compared.

\section{Case study characteristics}

Meybod city is located in Yazd province, central Iran (Fig. 1), with Quaternary sediments as the major geological units (Fig. 2). The major types of sediment in the area are clay 

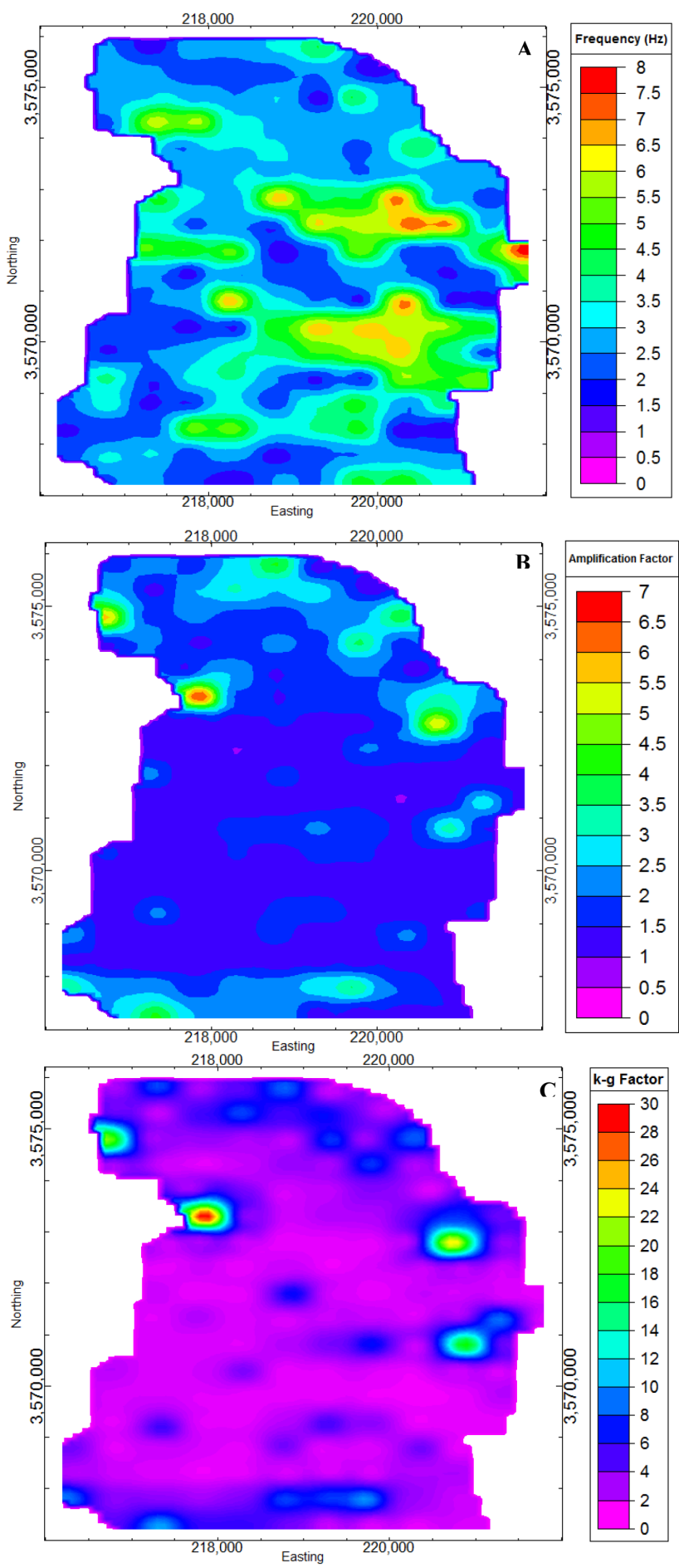

Figure 4. Data distribution maps of Meybod city: (a) frequency; (b) amplification; (c) $K-g$ value.

and silty-clay. Additionally, sandy-clay units occur in the NE part of the city with $2 \mathrm{~m}$ thickness and at depth of $30-32 \mathrm{~m}$.

Based on the geotechnical studies of the region, the dominant soil type is composed of clay and silt with high plasticity (Fig. 3). There is no major variation in the composition
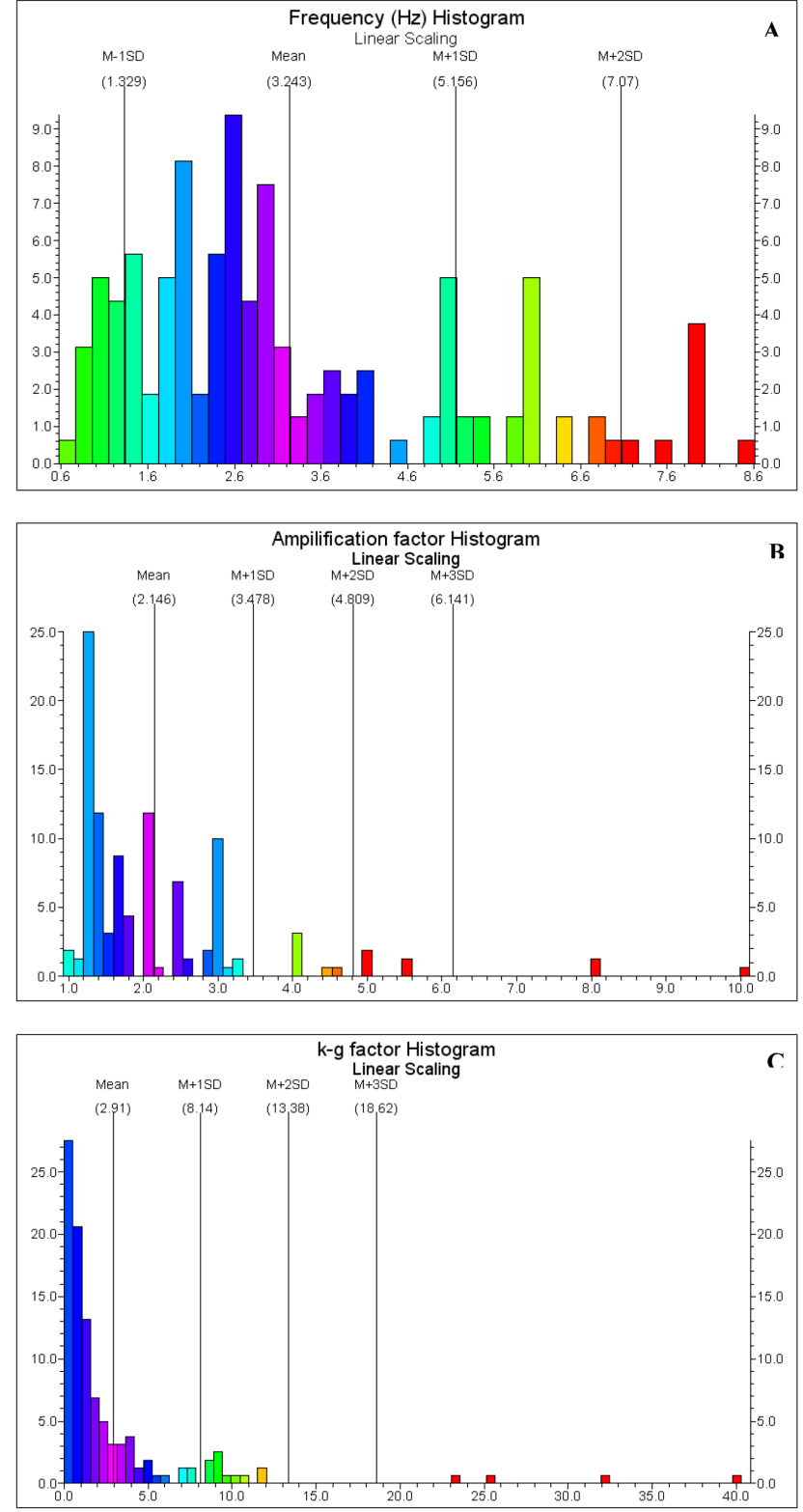

Figure 5. Data histograms showing multimodality of the factors: (a) frequency, (b) amplification, (c) $K-g$ value.

of sediment in the area, except for some variation of clay and silt contents in the eastern part (based on borehole data) (Fig. 3).

From the downhole data collected from five boreholes, the variations of $P$ and $S$ velocity $\left(\mathrm{m} \mathrm{s}^{-1}\right)$ were calculated (Table 3). Shear wave velocity is between 560 and $725 \mathrm{~m} \mathrm{~s}^{-1}$ at the depth of $42 \mathrm{~m}$. The depth of seismic bedrock varies from 52 to $90 \mathrm{~m}$ which is calculated based on the velocity. This result shows that there are differences in soil hardness values within the area. 
Table 3. Velocity of seismic waves $\left(\mathrm{m} \mathrm{s}^{-1}\right)$ in Meybod city.

\begin{tabular}{|c|c|c|c|c|c|c|c|c|c|c|}
\hline \multirow{2}{*}{$\begin{array}{l}\text { Borehole } \\
\operatorname{Depth}(\mathrm{m})\end{array}$} & \multicolumn{2}{|c|}{ B.H1 } & \multicolumn{2}{|c|}{ B.H2 } & \multicolumn{2}{|c|}{ B.H3 } & \multicolumn{2}{|c|}{ B.H4 } & \multicolumn{2}{|c|}{ B.H5 } \\
\hline & Vs & $\mathrm{Vp}$ & Vs & $\mathrm{Vp}$ & Vs & $\mathrm{Vp}$ & Vs & $\mathrm{Vp}$ & Vs & $\mathrm{Vp}$ \\
\hline 1.0 & 243 & 567 & 308 & 659 & 217 & 477 & 157 & 353 & 352 & 782 \\
\hline 2.0 & 329 & 743 & 356 & 759 & 283 & 615 & 225 & 501 & 415 & 905 \\
\hline 4.0 & 441 & 961 & 440 & 936 & 360 & 784 & 311 & 685 & 520 & 1100 \\
\hline 6.0 & 505 & 1081 & 464 & 997 & 407 & 882 & 377 & 820 & 548 & 1155 \\
\hline 8.0 & 532 & 1132 & 487 & 1045 & 451 & 968 & 405 & 881 & 561 & 1177 \\
\hline 10.0 & 521 & 1121 & 505 & 1080 & 473 & 1015 & 428 & 927 & 568 & 1192 \\
\hline 12.0 & 517 & 1121 & 523 & 1114 & 503 & 1070 & 449 & 969 & 592 & 1231 \\
\hline 14.0 & 505 & 1108 & 537 & 1141 & 525 & 1111 & 476 & 1019 & 612 & 1262 \\
\hline 16.0 & 490 & 1086 & 551 & 1164 & 525 & 1118 & 494 & 1053 & 625 & 1286 \\
\hline 18.0 & 493 & 1093 & 564 & 1188 & 528 & 1130 & 507 & 1078 & 628 & 1292 \\
\hline 20.0 & 497 & 1097 & 573 & 1207 & 535 & 1142 & 506 & 1081 & 643 & 1316 \\
\hline 22.0 & 503 & 1108 & 585 & 1228 & 550 & 1169 & 512 & 1094 & 651 & 1330 \\
\hline 24.0 & 509 & 1119 & 595 & 1244 & 562 & 1190 & 522 & 1113 & 662 & 1345 \\
\hline 26.0 & 518 & 1135 & 602 & 1256 & 575 & 1211 & 525 & 1121 & 672 & 1361 \\
\hline 28.0 & 526 & 1149 & 605 & 1263 & 585 & 1227 & 532 & 1134 & 683 & 1377 \\
\hline 30.0 & 534 & 1163 & 609 & 1271 & 592 & 1240 & 543 & 1152 & 692 & 1390 \\
\hline 32.0 & 539 & 1169 & 616 & 1283 & 601 & 1254 & 552 & 1168 & 700 & 1403 \\
\hline 34.0 & 541 & 1172 & 624 & 1295 & 603 & 1259 & 562 & 1184 & 703 & 1411 \\
\hline 36.0 & 545 & 1176 & 631 & 1306 & 610 & 1269 & 571 & 1197 & 708 & 1419 \\
\hline 38.0 & 551 & 1185 & 637 & 1315 & 617 & 1280 & 577 & 1208 & 714 & 1428 \\
\hline 40.0 & 555 & 1192 & 644 & 1325 & 623 & 1291 & 581 & 1215 & 719 & 1436 \\
\hline 42.0 & 559 & 1199 & 650 & 1335 & 629 & 1301 & 588 & 1226 & 725 & 1444 \\
\hline $\begin{array}{l}\text { Vs30 } \\
\left(\mathrm{m} \mathrm{s}^{-1}\right)\end{array}$ & 473 & & 509 & & 460 & & 407 & & 579 & \\
\hline $\begin{array}{l}\text { seismic bed } \\
\text { rock depth }(\mathrm{m})\end{array}$ & 70 & & 90 & & 80 & & 80 & & 52 & \\
\hline
\end{tabular}

Vs: Shear wave velocity, Vp: Longitudinal wave velocity.

Table 4. Comparison of frequency separation by $C-A$ fractal model and Nogoshi and Igarashi (1970, 1971).

\begin{tabular}{lrrr}
\hline \multicolumn{2}{l}{ Nogoshi and Igarashi } & \multicolumn{2}{c}{$C-A$ fractal model } \\
\hline $\begin{array}{l}\text { Ground } \\
\text { type }\end{array}$ & $\begin{array}{r}\text { Frequency } \\
(\mathrm{Hz})\end{array}$ & Category & $\begin{array}{r}\text { Frequency } \\
(\mathrm{Hz})\end{array}$ \\
\hline $7-10$ & I & $6.2-8$ & 4 \\
$4.5-7$ & II & $4.9-6.2$ & 3 \\
$2-4.5$ & III & $2.4-4.9$ & 2 \\
$0.1-2$ & IV & $0-2.4$ & 1 \\
\hline
\end{tabular}

\section{Methodology}

Microtremor data were recorded as single-point measuring and analyzed by the Nakamura technique (HVSR: Nakamura, 1989). To obtain the $H / V$ ratio of the data, we used SESAME software by applying fast Fourier transform (FFT). The results were mapped by the inverse distance squared (IDS) method using Rockworks TM v.15 software package. The results are fundamental frequency, amplification and ground vulnerability index ( $K-g$ value); the $K-g$ value is obtained by (Nakamura, 1997)

$K g=\left(A_{0}\right)^{2} / F_{0}$,

where $F_{0}$ and $A_{0}$ are predominant frequency and its amplification factor, and $K-g$ is an index to indicate the ease of deformation of measured points which is expected to be useful to detect weak points of the ground (Nakamura, 1997).

For instance, $K-g$ values obtained in San Francisco Bay area after the 1989 Loma-Prieta earthquake are bigger than 20 at the sites where grounds were deformed significantly and very small at the sites with no damage (Nakamura and Takizawa, 1990). However, comparison between $K-g$ values obtained before the earthquake in 1994 and the damage degrees show that places with large $K-g$ values correspond to the sites with big damage. This suggests that $K-g$ values represent the vulnerability precisely (Nakamura, 1997). 

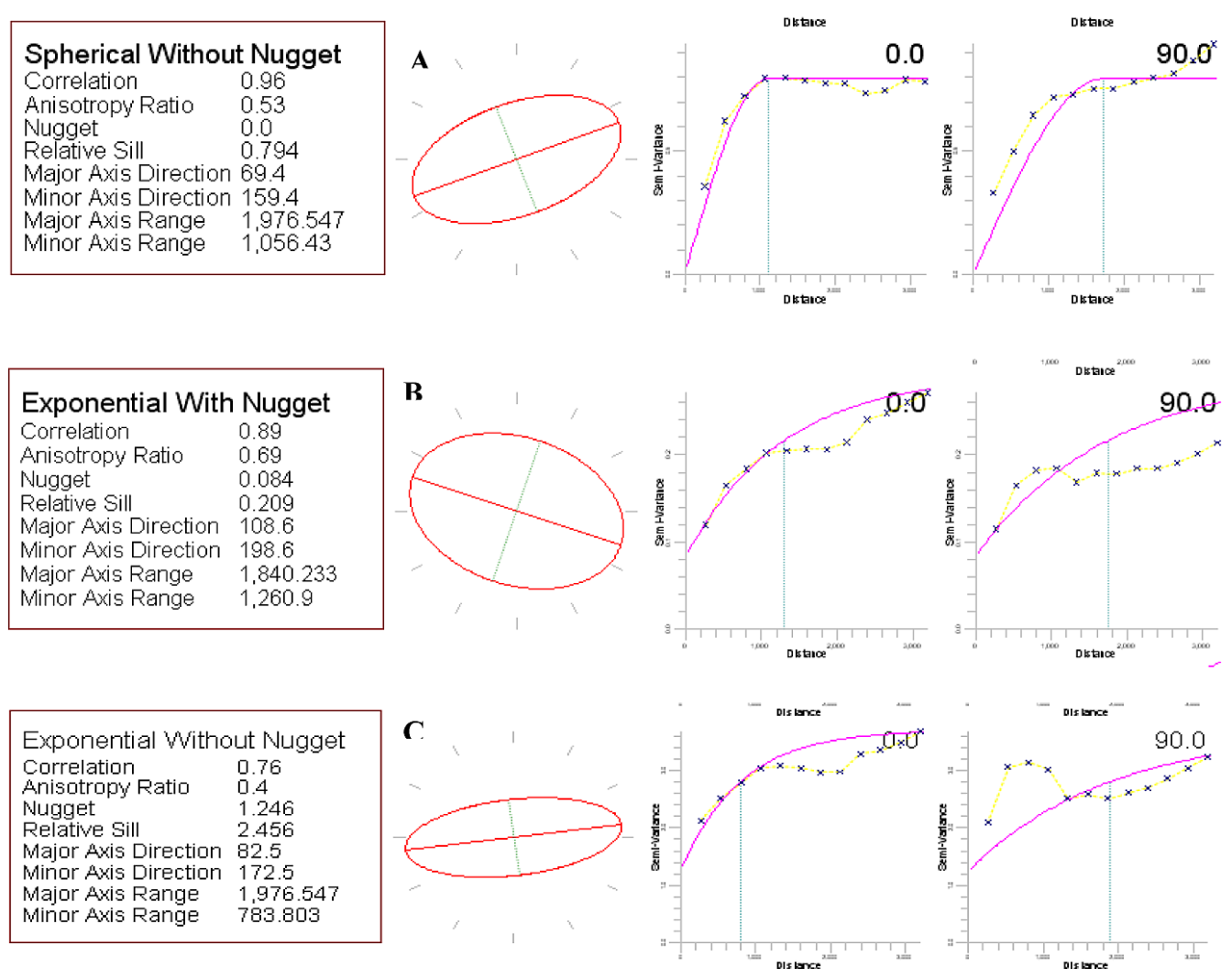

Figure 6. Variograms and anisotropic ellipsoids of the parameters: (a) frequency; (b) amplification; (c) $K-g$ value.

\section{Concentration-area fractal model}

Cheng et al. (1994) proposed the concentration-area $(C-A)$ model, which may be used to define the geophysical background and anomalies. The model is in the following general form:

$A(\rho \leq v) \propto \rho^{-a 1} ; A(\rho \geq v) \propto \rho^{-a 2}$

where $A(\rho)$ is the area with concentration values (frequency, amplification and $K-g$ in this study) greater than the contour value $\rho ; v$ is the threshold; and a1 and a2 are characteristic exponents.

The frequency size distributions for islands, earthquakes, fragments, ore deposits and oil fields often confirm the Eq. (2) (Daneshvar Saein et al., 2012). The two approaches which were used to calculate $A(\rho)$ by Cheng et al. (1994) were: (1) the $A(\rho)$ is the area enclosed by contour level $\rho$ on a variables' contour map resulting from interpolation of the original data using a weighted moving average method, and (2) the $A(\rho)$ are the values that are obtained by boxcounting of original regional variables' values. The breaks between straight-line segments on the $C-A \log -\log$ plot and the corresponding values of $\rho$ are used as thresholds to separate geophysical values into various components, showing different causal factors, such as lithological and mineralogical differences, geochemical and geophysical processes and mineralizing events (Lima et al., 2003; Afzal et al., 2010, 2012; Heidari et al., 2013).

Fractal models are often used to describe self-similar geometries, while multifractal models have been utilized to quantify patterns, similarly to geophysical data defined on sets which themselves can be fractals. Extension from geometry to field has considerably increased the applicability of fractal/multifractal modelling (Cheng, 2007). Multifractal theory can be interpreted as a theoretical framework that explains the power-law relationships between areas enclosing concentrations below a given threshold value and the actual concentrations themselves. To demonstrate and prove that data distribution has a multifractal nature requires a rather extensive computation (Halsey et al., 1986; Evertz and Mandelbrot, 1992). This method has several limitations such as accuracy problems, especially when the boundary effects on irregular geometrical data sets are involved (Agterberg et al., 1996; Goncalves, 2001; Cheng, 2007; Xie et al., 2010).

The $C-A$ model seems to be equally applicable to all cases, which is probably rooted in the fact that geophysical distributions mostly satisfy the properties of a multifractal function. Some evidence shows that geophysical data distributions are fractal in nature and behaviour (e.g. Bolviken et al., 1992; Turcotte, 1997; Gettings, 2005; Afzal et al., 2012; Daneshvar Saein et al., 2012). 


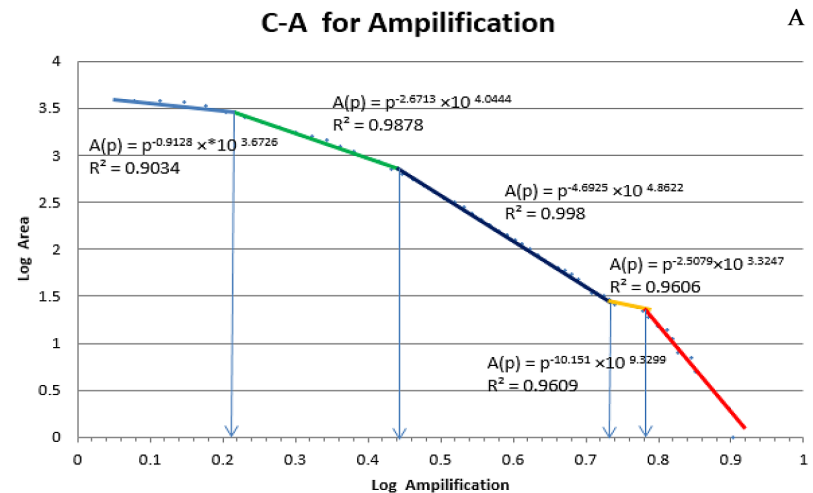

C-A for Frequency $(\mathrm{Hz})$

B

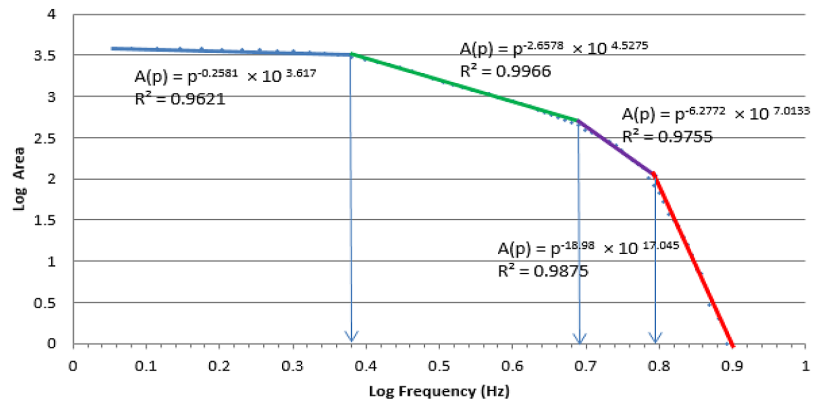

C-A for k-g

C

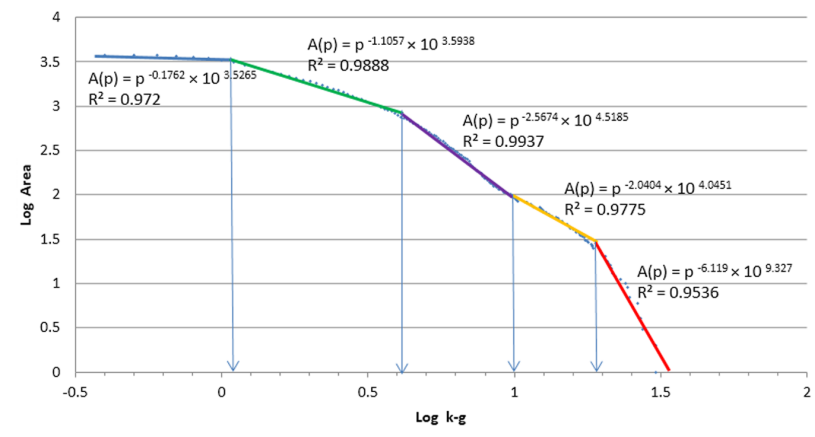

Figure 7. $C-A \log -\log$ plot for the parameters: (a) frequency, (b) amplification, (c) $K-g$ value.

This idea may help the development of an alternative interpretation validation as well as useful methods to be applied to geophysical distribution analysis (Afzal, 2012). Various $\log -\log$ plots between a geometrical character such as area, perimeter or volume and a geophysical quality parameter like geoelectrical data in fractal methods are appropriate for distinguishing geological recognition and population classification in geophysical data because threshold values can be identified and delineated as breakpoints in those plots (Daneshvar Saein et al., 2012).

\section{Application of $C-A$ model}

Microtremor data are measured at 160 points in the study area (Fig. 1) using a three-channel seismometer device (SL07, SARA Company, Italy). It has a natural frequency of $2 \mathrm{~Hz}$ and natural attenuation of 0.7 . This device has a 24-bit three-channelled digitizer, a central processing unit (CPU) to save records and a GPS receiver. The data were recorded with a sampling frequency of $200 \mathrm{~Hz}$ and the average recording time of 12 minutes at each station. First, a mesh was overlaid on the city map to determine the recording points. Then, recording at every point was regularly performed. When any recording point was not appropriate for recording (e.g. because of the existence of tall buildings), the point location was slightly shifted to achieve clear data. Moreover, if any point was approximate to a heavy traffic street, the data were recorded at midnight. During the recording process, the device was located on level ground and was balanced. Usually, $10 \mathrm{~min}$ is required for any microtremor recording to record the minimum $1 \mathrm{~Hz}$ frequency (WP12 SESAME project, 2004).

The obtained frequencies, amplifications and $K-g$ values are illustrated as contour maps applying the IDS interpolation method (Fig. 4). Areas with different frequencies can be visually distinguished in the map. The studied area was gridded by $20 \times 20 \mathrm{~m}$ cells. The evaluated values in cells were sorted based on decreasing grades, and cumulative areas were calculated for grades. Finally, log-log graphs were plotted to separate the different populations.

Distributions of the fundamental frequency, amplification and $K-g$ data are multimodal with mean values of $3.24 \mathrm{~Hz}$, 2.14 and 2.91, respectively (Fig. 5). The separated populations are clear in their histograms and also, high amounts of the parameters are lower than their means. The median were assumed for their threshold values because their distributions are not normal. The medians are $2.6 \mathrm{~Hz}, 1.6$ and 1.1 for frequency, amplification and $K-g$ respectively. The median values of these parameters are low for their threshold values. Variograms and anisotropic ellipsoids of the parameters were calculated to estimate the data influence range of any point in order of plotting IDS maps (Fig. 6). These ellipsoids make the results estimated more accurate and we can determine the direction of the result variations. Based on the variograms and ellipsoids of the parameters, their major ranges have a W-E trend. This can be seen in the direction of soil variations that become more intense from west to east of the area (Fig. 3).

According to the $C-A \log -\log$ plots, four populations were distinguished for the frequency and five populations for the amplification and $K-g$ which reveals the multifractal nature of the parameters in Meybod city, as shown in Fig. 7. The multifractal nature of frequency, amplification and $K$ $g$ is based on there being more than two straight segments. The straight segment fitted lines were derived based on leastsquare regression (Spalla et al., 2010). All $R$-squared values 

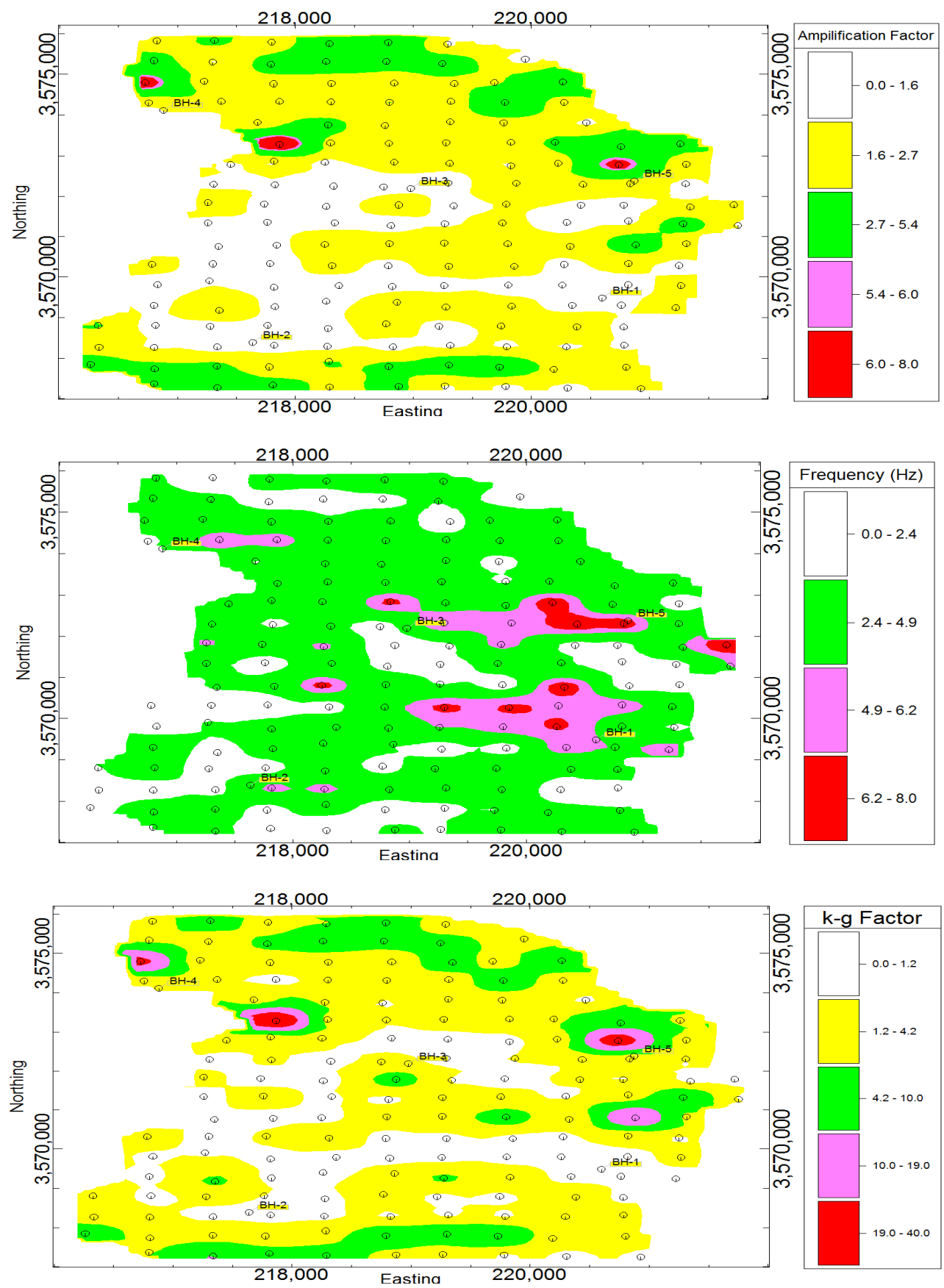

Figure 8. Data classification based on the $C-A$ method: (a) frequency, (b) amplification, (c) $K-g$ value.

Table 5. Frequency of amplification and $K-g$ classes in every frequency category.

\begin{tabular}{|c|c|c|c|c|c|c|c|c|c|c|}
\hline \multirow{2}{*}{$\begin{array}{l}\text { Frequency } \\
\text { classes }(\mathrm{Hz})\end{array}$} & \multicolumn{5}{|c|}{ Amplification classes } & \multicolumn{4}{|c|}{$K-g$ classes } & \multirow[b]{2}{*}{$19-40$} \\
\hline & $<1.6$ & $1.6-2.7$ & $2.7-5.4$ & $5.4-6$ & $6-10$ & $<1.2$ & $1.2-4.2$ & $4.2-10$ & $10-19$ & \\
\hline $6.2-8$ & 4 & 10 & 0 & 0 & 0 & 14 & 0 & 0 & 0 & 0 \\
\hline $4.9-6.2$ & 15 & 5 & 2 & 0 & 0 & 19 & 3 & 0 & 0 & 0 \\
\hline $2.4-4.9$ & 22 & 21 & 12 & 2 & 2 & 28 & 25 & 3 & 1 & 2 \\
\hline$<2.4$ & 28 & 18 & 18 & 0 & 1 & 20 & 24 & 16 & 3 & 2 \\
\hline
\end{tabular}




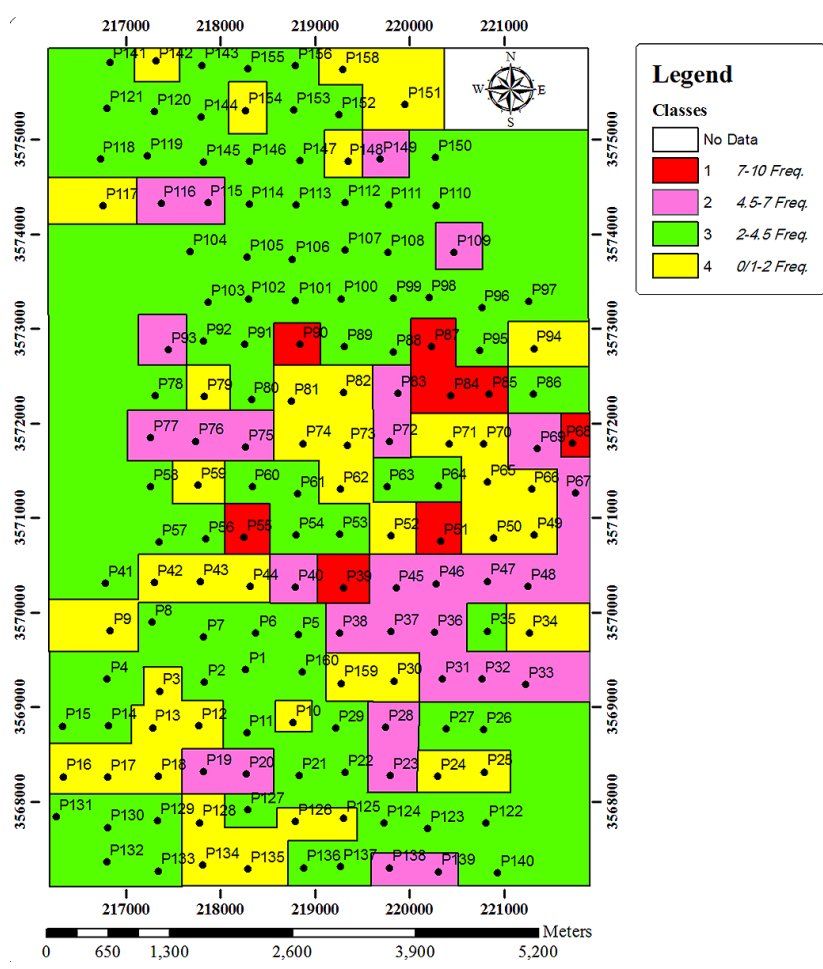

Figure 9. Ground type zonation of the region based on Nogoshi and Igarashi $(1970,1971)$.

are higher than 0.9 and most of them have $R^{2}$ higher than 0.95 which indicates a good straight-line fitting of the populations (Fig. 7). The power-law relationships between the geophysical parameters and their occupied areas are shown in Fig. 7. According to Eq. (2), there are different values for $\alpha$ which is the fractal dimension exponent, as in Fig. 7. The variation of fractal dimension reveals the multifractal nature of frequency, amplification and $K-g$ in the area. Moreover, a sudden exchange shows different populations in the log-log plots especially in the last population (Fig. 7). The data distribution based on the $C-A$ model is shown in Fig. 8. The sites with high intensity values of frequency are situated in the central parts of the area and the sites with high-intensity amplification and $K-g$ are located in the northern and eastern parts of Meybod city.

Most of the city has frequency lower than $4.9 \mathrm{~Hz}$, generally between 2.4 to $4.9 \mathrm{~Hz}$. The central part of the city is the only part with high frequency, as shown in Fig. 8. This indicates that it is more competent than the other parts. Based on the resulting frequencies, most parts of the city contain soft soils, but amplification and $K-g$ quantities are very low, lower than 2.4 and 4.2 , respectively.
Table 6. Site effect classification based on the $C-A$ method.

\begin{tabular}{lrrr}
\hline $\begin{array}{l}\text { Site } \\
\text { description }\end{array}$ & $\begin{array}{r}\text { Frequency } \\
(\mathrm{Hz})\end{array}$ & Amplification & $K-g$ \\
\hline Hard soil, weak rock & $6.2-8$ & $<2.7$ & $<1.2$ \\
Stiff soil & $4.9-6.2$ & $<5.4$ & $<4.2$ \\
Moderately soft soil & $2.4-4.9$ & $<10$ & $\leq 40$ \\
Soft soil & $0-2.4$ & $<10$ & $\leq 40$ \\
\hline
\end{tabular}

\section{Comparison between Nogoshi classification and Fractal modelling results}

Site classification of the city is calculated based on the Nogoshi and Igarashi method $(1970,1971)$ which is a common classification for microtremor analysis. The basis of this classification is fundamental frequency; thus, with regard to the obtained frequencies, the ground type of Meybod is identified as shown in Table 3 and Fig. 9.

Comparison between the $C-A$ fractal model and Nogoshi classification shows that the thresholds obtained by the two methods are similar (Table 4). Indeed it can be said that by frequency separation resulting from the fractal $C-A$ model, we can identify minor data anomalies and consequently classify site effect results more accurately. Therefore, by this approach other results due to frequency can be classified and then every category attributed to one specific ground type.

From comparison of the soil zonation maps, it is obvious that there are five categories for amplification and $K-g$ value. Meanwhile, there are four categories due to frequency and ground classification. Generally, the amplification of the city is low because of very low variation in the soil composition. Based on the amplification and $K-g$ values (Table 5) of every frequency category, appropriate quantities of amplification and vulnerability index in any resulting classes of the $C-A$ fractal model were derived (Table 6). Accordingly, amplification and $k-g$ in any frequency category are: lower than 2.7 and lower than 1.2 respectively for frequency between $6.2-8 \mathrm{~Hz}$, lower than 5.4 and lower than 4.2 respectively for frequency $4.9-6.2$ and lower than or equal to 10 and 40 respectively for the other two frequency groups.

Based on the results obtained by shear-wave velocity calculation in the boreholes and results derived via the $C-A$ fractal model, the velocities were correlated with threshold values of the $C-A$ model (Table 3 ).

\section{Conclusions}

The $C-A$ fractal model is a useful approach in geophysical analysis to identify anomalies and geological particulars and this has been proved by numerous studies. Also this method could be appropriate for geophysical distribution analysis due to its fractal nature. 
In this study, due to comparing site effect classification of the area based on Nogoshi and Igarashi classification and frequency categorization resulting from the $C-A$ fractal model, it is obtained that the $C-A$ fractal model is a useful tool to distinguish and classify site effect results, so that category boundaries can be recognized more accurately. We can also attribute resulting frequency, amplification and vulnerability index to any site class more confidently. Additionally, the thresholds derived via Nogoshi and Igarashi classification for the region were corrected. Accordingly, four site classes were obtained for the city as follows:

- Category 1 (weak rock, hard soil): frequency $6.2-8 \mathrm{~Hz}$, amplification lower than 2.7 and vulnerability index lower than 1.2. This exists at some points in the centre of the city toward the east.

- Category 2 (stiff soil): frequency 4.9-6.2 Hz, amplification lower than 5.4 and vulnerability index lower than 4.2. This exists mostly in the central parts of the city.

- Category 3 (moderately soft soil): frequency 2.4$4.9 \mathrm{~Hz}$, amplification lower than 10 and vulnerability index lower than or equal to 40 . This exists in most parts of the city.

- Category 4 (soft soil): frequency lower than $2.4 \mathrm{~Hz}$, amplification lower than 10 and vulnerability index lower than or equal to 40 , similar to category 3 . This is scattered in different parts of the city such as east and SE, west and SW, centre and NW.

Acknowledgements. The authors thank Islamic Azad University, South Tehran branch for support of this research. In addition, the authors acknowledge Gholamreza Shoaei (Assistant Professor at Engineering Geology Group, Geology Section, Tarbiat Modares University) and Alireza Ashofteh for their remarkable contribution.

Edited by: S. Lovejoy

Reviewed by: A. B. Yasrebi and one anonymous referee

\section{References}

Afzal, P., Fadakar Alghalandis, Y., Khakzad, A., Moarefvand, P., and Rashidnejad Omran, N.: Delineation of mineralization zones in porphyry $\mathrm{Cu}$ deposits by fractal concentration-volume modeling, J. Geochem. Explor., 108, 220-232, 2011.

Afzal, P., Dadashzadeh Ahari, H., Rashidnejad Omran, N., and Aliyari, F.: Delineation of gold mineralized zones using concentration-volume fractal model in Qolqoleh gold deposit, NW Iran, Ore Geol. Rev., 55, 125-133, 2013.

Afzal, P., Zia Zarifi, A., and Bijan Yasrebi, A.: Identification of uranium targets based on airborne radiometric data analysis by using multifractal modeling, Tark and Avanligh 1:50 000 sheets, NW Iran, Nonlin. Processes Geophys., 19, 283-289, doi:10.5194/npg-19-283-2012, 2012.
Afzal, P., Khakzad, A., Moarefvand, P., Rashidnejad Omran, N., Esfan-diari, B., and Fadakar Alghalandis, Y.: Geochemical anomaly separation by multifractal modeling in Kahang (Gor Gor) porphyry system, Central Iran, J. Geochem. Exp., 104, 3446, 2010.

Agterberg, F. P., Cheng, Q., Brown, A., and Good, D.: Multifractal modeling of fractures in the Lac du Bonnet batholith, Manitoba, Comput. Geosci., 22, 497-507, 1996.

Akamatu, K.: On microseisms in frequency range from $1 \mathrm{c} / \mathrm{s}$ to 200 c/s, Bull. Earthquake Res. Inst., 39, 23-75, 1961.

Allam, A. M.: An Investigation Into the Nature of Microtremors Through Experimental Studies of Seismic Waves, University of Tokyo, p. 326, 1969.

Architectural Institute of Japan: Earthquake Motion and Ground Condition, AIJ, AIJ, 5-26-20 Shiba, Minato-ku, Tokyo 108, Japan, 1993.

Bard, P. Y.: Microtremor measurements: a tool for site effects estimation? Proceedings of the Second International Symposium on the effects of Surface Geology on Seismic Motion, Yokohama, Japan, December 1998, 1251-1279, 1998TS5, 1998.

Bard, P. Y.: Lecture notes on "Seismology, Seismic Hazard Assessment and Risk Mitigation", International Training Course, Potsdam, p. 160, 2000.

Beroya, M. A. A., Aydin, A., Tiglao, R., and Lasala, M.: Use of microtremor in liquefaction hazard mapping, Eng. Geol., 107, 140-153, 2009.

Bolviken, B., Stokke, P. R., Feder, J., Jossang, T.: The fractal nature of geochemical landscapes. J. Geochem. Explor., 43, $91-$ 109, 1992.

Cheng, Q., Agterberg, F. P., and Ballantyne, S. B.: The separartion of geochemical anomalies from background by fractal methods, J. Geochem. Explor., 51, 109-130, 1994.

Cheng, Q.: Spatial and scaling modelling for geochemical anomaly separation, J. Geochem. Explor., 65, 175-194, 1999.

Cheng, Q.: Mapping singularities with stream sediment geochemical data for prediction of undiscovered mineral deposits in Gejiu, Yunnan Province, China, Ore Geol. Rev., 32, 314-324, 2007.

Daneshvar Saein, L., Rasa, I., Rashidnejad Omran, N., Moarefvand, P., and Afzal, P.: Application of concentration-volume fractal method in induced polarization and resistivity data interpretation for $\mathrm{Cu}-\mathrm{Mo}$ porphyry deposits exploration, case study: Nowchun $\mathrm{Cu}-\mathrm{Mo}$ deposit, SE Iran, Nonlin. Processes Geophys., 19, 431438, doi:10.5194/npg-19-431-2012, 2012.

Davis, J. C.: Statistics and data analysis in Geology, 3th Edn., John Wiley \& Sons Inc., New York, p. 638, 2002.

Douze, E. J.: Rayleigh waves in short period seismic noise, Bull. Seismol. Soc. Am., 54, 1197-1212, 1964.

Duval, A. M.: Détermination de la résponse d'un site aux séismes à l'aide du bruit de fond: Evaluation expérimentale, $\mathrm{PhD}$ Thesis, Université Pierre et Marie Curie, Paris 6, 1994 (in French).

Duval, A. M.: Détermination de la réponse d'un site aux séismes à l'aide du bruit de fond, Evaluation expérimentale, Etudes et Recherches des Laboratories des Ponts et Chaussées, Série Géotechnique, ISSN 1157-39106, 264 pp., Paris: Laboratoire central des ponts et chausseìes, ISBN 2-7208-2480-1, 264 pp., 1996 (in French).

Evertz, C. J. G. and Mandelbrot, B. B.: Multifractal measures (appendix B), in: Chaos and Fractals, edited by: Peitgen, H.-O., Jurgens, H., and Saupe, D., Springer, New York, p. 953, 1992. 
Gettings, M. E.: Multifractal magnetic susceptibility distribution models of hydrothermally altered rocks in the Needle Creek Igneous Center of the Absaroka Mountains, Wyoming, Nonlin. Processes Geophys., 12, 587-601, doi:10.5194/npg-12-5872005, 2005.

Goncalves, M. A.: Characterization of geochemical distributions using multifractal models, Math. Geol., 33, 41-61, 2001.

Goncalves, M. A., Mateus, A., and Oliveira, V.: Geochemical anomaly separation by multifractal modeling, J. Geochem. Explor., 72, 91-114, 2001.

Gosar, A., Stoper, R., and Roser, J.: Comparative test of active and passive multichannel analysis of surface waves (MASW) methods and microtremor HVSR method, RMZ Material Geoenviron., 55, 41-66, 2008.

Halsey, T. C., Jensen, M. H., Kadanoff, L. P., Procaccia, I., and Shraiman, B. I.: Fractal measures and their singularities: the characterization of strange sets, Phys. Rev. A, 33, 1141-1151, 1986.

Heidari, S. M., Ghaderi, M., and Afzal, P.: Delineating mineralized phases based on lithogeochemical data using multifractal model in Touzlar epithermal Au-Ag $(\mathrm{Cu})$ deposit, NW Iran, Appl. Geochem., 31, 119-132, 2013.

Kamalian, M., Jafari, M. K., Ghayamghamian, M. R., Shafiee, A., Hamzehloo, H., Haghshenas, E., and Sohrabi-bidar, A.: Site effect microzonation of Qom, Iran, Eng. Geol., 97, 63-79, 2008

Kanai, K. and Tanaka, T.: Measurement of the microtremor I, Bull. Earthq. Res. Institute, 32, 199-209, 1954.

Komak Panah, A., Hafezi Moghaddas, N., Ghayamghamian, M. R., Motosaka, M., Jafari, M. K., and Uromieh, A.: Site Effect Classification in East-Central of Iran, J. Seismol. Earthq. Eng., 4, 3746, 2002.

Konno, K. and Ohmachi, T.: ground motion characteristics estimated from spectral ratio between horizontal and vertical components of microtremor, Bull. Seismol. Soc. Am., 88, 228-241, 1998.

Lima, A., De Vivo, B., Cicchella, D., Cortini, M., and Albanese, S.: Multifractal IDW interpolation and fractal filtering method in environmental studies: an application on regional stream sediments of (Italy), Campania region, Appl. Geochem., 18, 1853-1865, 2003.

Mandelbrot, B. B.: The Fractal Geometry of Nature, W. H. Freeman, San Fransisco, p. 468, 1983.
Mukhopadhyay, S. and Bormann, P.: Low cost seismic microzonation using microtremor data: an example from Delhi, India, J. Asian Earth Sci., 24, 271-280, 2004.

Nakamura, Y.: A method for dynamic characteristics estimation of subsurface using microtremor on the ground surface, Quarterly report of Railway Technical Res. Inst. (RTRI), 30, 25-33, 1989.

Nakamura, Y.: Seismic vulnerability indices for ground and structures using microtremor, World Congress on Railway Research in Florence, Italy, 1997.

Nakamura, Y. and Takizawa, T.: Evaluation of Liquefaction of Surface Ground using Microtremor (in Japanese), Proc. 45th Annual Meeting of JSCE, I-519, 1068-1069, 1990.

Nogoshi, M. and Igarashi, T.: On the amplitude characteristics of microtremor (Part 2), J. Seismol. Soc. JPN, 24, 26-40, 1971 (in Japanese with English abstract).

Nogoshi, M. and Igarashi, T.: On the propagation characteristics of microtremors, J. Seismol. Soc. JPN, 23, 264-280, 1970.

SESAME, European research project WP12: Guidelines for the implementation of the $H / V$ spectral ratio technique on ambient vibrations: measurements, processing and interpretation, available at: http://sesame-fp5.obs.ujf-grenoble.fr/Delivrables/ Del-D23-HV_User_Guidelines.pdf (last access: July 2011), 2004.

Sim, B. L., Agterberg, F. P., and Beaudry, C.: Determining the cutoff between background and relative base metal contamination levels using multifractal methods, Comput. Geosci., 25, 1023-1041, 1999.

Spalla, M. I., Morotta, A. M., and Gosso, G.: Advances in interpretation of geological processes: refinement of multi-scale data and integration in numerical modelling, Geological Society, London, p. 240, 2010.

Turcotte, D. L.: A fractal approach to the relationship between ore grade and tonnage, Econ. Geol., 18, 1525-1532, 1986.

Turcotte, D. L.: Fractals and chaos in geology and geophysics, Cambridge University Press, Cambridge, 1997.

Xie, S., Cheng, Q., Zhang, S., and Huang, K.: Assessing microstructures of pyrrhotites in basalts by multifractal analysis, Nonlin. Processes Geophys., 17, 319-327, doi:10.5194/npg-17-3192010, 2010. 